\title{
Plant Responses to an Integrated Cropping System Designed to Maintain Yield Whilst Enhancing Soil Properties and Biodiversity
}

\author{
Cathy Hawes ${ }^{1, *}$, Colin J. Alexander ${ }^{2}{ }^{(1)}$, Graham S. Begg ${ }^{1}$, Pietro P. M. Iannetta ${ }^{1}{ }^{(\mathbb{C} \text {, }}$ \\ Alison J. Karley ${ }^{1}{ }^{\mathbb{D}}$, Geoffrey R. Squire ${ }^{1}$ and Mark Young ${ }^{1}$ \\ 1 James Hutton Institute, Invergowrie, Dundee DD2 5DA, Scotland, UK; Graham.Begg@hutton.ac.uk (G.S.B.); \\ Pete.Iannetta@hutton.ac.uk (P.P.M.I.); Alison.Karley@hutton.ac.uk (A.J.K.); \\ Geoff.Squire@hutton.ac.uk (G.R.S.); Mark.Young@hutton.ac.uk (M.Y.) \\ 2 Biomathematics and Statistics Scotland, Invergowrie, Dundee DD2 5DA, Scotland, UK; \\ Colin.Alexander@hutton.ac.uk \\ * Correspondence: Cathy.Hawes@hutton.ac.uk; Tel.: +44-344-928-5428
}

Received: 20 September 2018; Accepted: 9 October 2018; Published: 17 October 2018

\begin{abstract}
The intensification of arable production since the 1950s has resulted in increases in yield but only at significant cost to the environment, raising serious concerns about long-term consequences for the sustainability of food production systems. While a range of policies and practices have been put in place to mitigate negative effects in terms of pollution, soil degradation and loss of biodiversity, their efficacy has not been properly quantified. Whole-system effects of management change are rarely studied and so trade-offs and conflicts between different components of the agricultural system are poorly understood. A long-term field platform was therefore established in which conventional arable management was compared with a low-input, integrated cropping system designed with the goal to maintain yields whilst enhancing biodiversity and minimizing environmental impact. Over the first rotation, only winter wheat yielded less under integrated management; yield was maintained for the remaining five crops (spring and winter barley, winter oilseed rape, potato and field beans), suggesting a negligible impact on economic returns. Beneficial broad-leaved weeds were significantly more abundant in the integrated management system across all crops whereas grass weeds showed no overall response to treatment. Soil carbon, $\mathrm{pH}$ and soil concentrations of the main plant growth-limiting macronutrients were enhanced under the integrated management system. The integrated system was therefore successful in meeting the goals to enhance biodiversity and reduce environmental impact without jeopardizing crop yields.
\end{abstract}

Keywords: integrated farm management; weed biodiversity; system trade-offs; long-term platform

\section{Introduction}

The intensification of arable production between the 1950s and 1990s resulted in increases in yield, primarily through targeted crop breeding programs and the supply of relatively cheap mineral fertilizer from the Haber-Bosch manufacture of nitrogen [1,2]. However, these yield gains were only achieved at significant cost to the environment: increased greenhouse gas emissions and agrochemical pollution of water [3]; loss of arable biodiversity resulting in negative effects on ecosystem function and services [4]; and degraded soil physical structure causing soil erosion and compaction, resulting in loss of soil, associated organisms and nutrients, restricted root growth and reduced plant resource use efficiency $[5,6]$. These trends have raised serious concerns about the long-term impacts of intensification on the sustainability of food production systems and there is increasing pressure on farmers to 
produce more food of high quality whilst at the same time protecting the environment and improving arable biodiversity.

In the UK and Europe, policies have been put in place to reduce emissions, create carbon sinks, preserve soil organic matter and increase biodiversity. These include agri-environment schemes offering compensation to farmers for environmental protection and biodiversity conservation [7], the Nitrates Directives (91/676/EEC) that restricts the application of nitrogen within Nitrate Vulnerable Zones (i.e., regions with $>50 \mathrm{mg} \mathrm{L}^{-1}$ nitrate in the ground water), EU CAP Greening measures and the United Nations Environment Programme's target to increase organic agriculture to 5-10\% of the EU agricultural area by 2020 [8].

Continued conventional intensification of European agriculture to maintain or increase yields would contravene these goals and cause further environmental degradation, reducing environmental and economic sustainability in the long-term. There are therefore two main options for reconciling the need to maintain yield whilst reducing the environmental footprint of agricultural production: either increase the total area of land under arable production (extensification); or increase the efficiency of production systems to generate more offtake per unit area without adverse environmental impact ("sustainable intensification"; [9]).

Agricultural land in Europe is approximately $20 \%$ of the total land area. Almost $60 \%$ of this agricultural land is in arable production and $38 \%$ is grazed (http:/ / en.worldstat.info/Europe/Land 2007 and 2011 data), indicating very limited opportunity for expansion of the total cropped area in Europe. In other parts of the world, the area of land suitable for agriculture is declining due to climate change and environmental degradation. Given these trends, together with ever tighter restrictions on the use of agrochemicals, food security goals must be met by increasing the efficiency of production within the existing cultivated area. To this end, a range of policies and practices have been considered to ameliorate degradation and begin regeneration. Soil conditions can be improved to enhance root growth and therefore resource availability to crop plants $[10,11]$. New crop varieties or crop combinations may be developed with more efficient conversion of acquired resource to yield (e.g., [1,12]). Losses from the system through greenhouse gas emissions, leaching and run-off can be reduced through increasing soil organic matter content, conservation tillage and the use of cover crops (e.g., [13]). Alternative sources of plant nutrients (e.g., from biological nitrogen fixation or recycled products and digestates) can be used to replace mineral fertilizers [14].

Achieving sustainable agricultural production in this way requires not only an understanding of specific processes within the cropping system but also knowledge of the long-term, whole-system responses to change in land management. However, whole-system effects of management change have been rarely studied and so trade-offs and conflicts between different components of the agricultural system are poorly understood. To address this deficiency, a long-term field platform was established at the Centre for Sustainable Cropping (CSC), Balruddery Farm, Dundee, UK $[15,16]$. The CSC compares current commercial practice with a low-input, integrated cropping system that combines many of the alternative management options referred to above. The integrated system aims to enhance biodiversity and reduce environmental impact for ecosystem functioning by minimizing inputs and losses of non-renewable resources, whilst maintaining crop yield for economic security. Here we test the prediction that, over the course of a six-year rotation, the integrated cropping system has a positive effect on soil properties $(\mathrm{pH}$, carbon and plant nutrient concentrations) and the abundance of beneficial within-field weeds but a minimal impact on crop yield relative to standard commercial practice. Trade-offs between management for maximum crop production, soil health and arable biodiversity are discussed.

\section{Materials and Methods}

\subsection{Field Site and Layout}

The Centre for Sustainable Cropping (CSC) was established in 2009 as a long-term platform for cross-disciplinary research on arable sustainability (http:/ / csc.hutton.ac.uk). The platform is based 
at Balruddery Farm, Dundee, north-east Scotland (56.48 latitude-3.13 longitude). Balruddery Farm is a 178 ha arable farm, $67 \mathrm{~m}$ to $163 \mathrm{~m}$ above sea level on the south facing slopes of the Sidlaw Hills. The farm is in a temperate Atlantic maritime arable environment, with an average annual rainfall of $800 \mathrm{~mm}$, an average annual accumulated temperature of 1100-1375 day-degrees $C$ (above $5.6^{\circ} \mathrm{C}$ ) and a mean annual potential water deficit of $50-75 \mathrm{~mm}$. The area is moderately exposed $\left(2.6-4.4 \mathrm{~m} \mathrm{~s}^{-1}\right.$ wind speed) and has moderate winters of 50-110 day degrees $C$ of accumulated frost. The soils are imperfectly draining Balrownie Series with an average $\mathrm{pH}$ of 5.7. Topsoil depths range from $25 \mathrm{~cm}$ to $40 \mathrm{~cm}$, textures from sandy loam to sandy silt loam and stone contents of $10-20 \%$ volume.

The CSC platform is a 42 ha contiguous block of six arable fields within the farm, based on a six year rotation of the commonly grown crops in the region: potatoes, winter wheat, winter barley, winter oilseed rape, spring sown fava beans and spring barley. The crop rotation is now fixed as this sequence but was altered in two of the six years of the first rotation to improve the timings of winter sowing relative to previous crop harvest (see csc.hutton.ac.uk for full details). Following two baseline years where all fields were sown with maize in spring 2009 and 2010 to provide a $C_{4}$ signature ( $\delta 13 C$ value -25.3 to $-26.0 \%$ ) for subsequent measures of carbon turnover (reported in Reference [17]), each of the six fields were divided in half. Conventional and integrated management treatments were randomly allocated to each half (Figure 1). Within each half field, five or six $18 \mathrm{~m}$ wide strips (depending on field size) were established to test the responses of five different cultivars of each crop to management treatment. Strip width was determined by machinery size (boom width) and therefore tramline spacing. Varieties were selected to include at least one industry standard and represent a range of desirable crop traits (e.g., resource use efficiency, weed competitiveness, pest and disease resistance). The same five varieties were sown in each half field for comparison of variety specific responses to the two cropping systems.

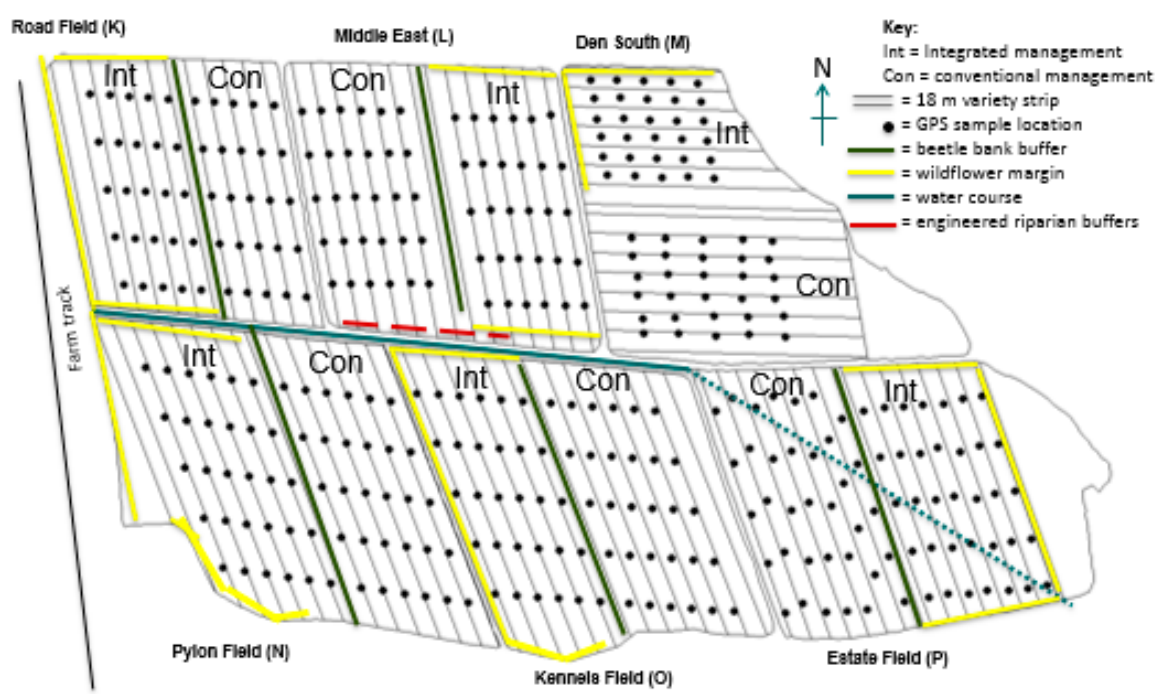

Figure 1. Layout of the six fields at the James Hutton Institute's Centre for Sustainable Cropping, Balruddery Farm, Dundee, UK.

\subsection{Cropping Systems}

The treatment allocations were made in autumn 2010 at the start of the experiment and will remain in place for the lifetime of the platform to allow assessment of the long-term cumulative effects on the arable ecosystem. The conventional treatment for each crop is the standard commercial practice for the region in terms of soil cultivation, fertilizer inputs and herbicide applications (Table 1) and is based on advice from an independent commercial agronomist who also routinely provides agronomic advice to farmers in the area. 
Table 1. Timings and details of field operations, fertilizer inputs and herbicide applications for conventional (conv) and integrated (integ) cropping systems across the six crops in the rotation. Cultivation method is either standard conventional plough (conv) or non-inversion tillage to $7 \mathrm{~cm}$ depth (non-inv). Differences in the integrated cropping system compared to standard practice are highlighted as shaded cells.

\begin{tabular}{|c|c|c|c|c|c|c|c|c|c|c|c|c|}
\hline & \multicolumn{2}{|c|}{ Potato } & \multicolumn{2}{|c|}{ Winter Wheat } & \multicolumn{2}{|c|}{ Beans } & \multicolumn{2}{|c|}{ Spring Barley } & \multicolumn{2}{|c|}{ Winter Oilseed } & \multicolumn{2}{|c|}{ Winter Barley } \\
\hline & conv & integ & conv & integ & conv & integ & conv & integ & conv & integ & conv & integ \\
\hline $\begin{array}{l}\text { Cultivation timing } \\
\text { Cultivation method }\end{array}$ & $\begin{array}{l}\text { Nov-Mar } \\
\text { conv }\end{array}$ & $\begin{array}{c}\text { Mar-Apr } \\
\text { conv }\end{array}$ & $\begin{array}{c}\text { Oct } \\
\text { conv }\end{array}$ & $\begin{array}{l}\text { Oct } \\
\text { conv }\end{array}$ & $\begin{array}{c}\text { Feb-Mar } \\
\text { conv }\end{array}$ & $\begin{array}{c}\text { Mar } \\
\text { non-inv }\end{array}$ & $\begin{array}{l}\text { Feb-Apr } \\
\text { conv }\end{array}$ & $\begin{array}{l}\text { Mar-Apr } \\
\text { non-inv }\end{array}$ & $\begin{array}{l}\text { Aug-Sep } \\
\text { conv }\end{array}$ & $\begin{array}{l}\text { Aug-Sep } \\
\text { non-inv }\end{array}$ & Aug-Sep & Aug-Sep \\
\hline Sowing/planting 1 & Apr & Apr & Oct & Oct & Mar-Apr & Mar-Apr & Mar-Apr & Mar-Apr & Aug-Sep & Aug-Sep & Sep & Sep \\
\hline Sowing/planting 2 & & & & & & & & $\begin{array}{l}\text { clover undersow } \\
\text { (Apr) }\end{array}$ & & & & $\begin{array}{c}\text { oil radish } \\
\text { cover (Aug) }\end{array}$ \\
\hline $\begin{array}{l}\text { Fertiliser } 1 \text { product } \\
\text { rate (kg/ha) }\end{array}$ & & $\begin{array}{c}\text { compost } \\
3500\end{array}$ & & $\begin{array}{c}\text { compost } \\
3500\end{array}$ & & $\begin{array}{c}\text { compost } \\
3500\end{array}$ & & $\begin{array}{c}\text { compost } \\
3500\end{array}$ & & $\begin{array}{c}\text { compost } \\
3500\end{array}$ & & $\begin{array}{l}\text { compost } \\
3500\end{array}$ \\
\hline Fertiliser 2 product & $14-14-21$ & $14-14-21$ & $30-0-0$ & $30-0-0$ & $0-20-30$ & $0-20-30$ & $30-0-0$ & $30-0-0$ & 17-17-17 & $17-17-17$ & $0-20-30$ & $0-20-30$ \\
\hline rate $(\mathrm{kg} / \mathrm{ha})$ & 1400 & 1050 & 300 & 225 & 200 & 150 & 380 & 285 & 170 & 120 & 300 & 225 \\
\hline Fertiliser 3 product & & & $30-0-0$ & $30-0-0$ & & & $0-0-60$ & $0-0-60$ & $30-0-0$ & $30-0-0$ & $30-0-0$ & $30-0-0$ \\
\hline rate $(\mathrm{kg} / \mathrm{ha})$ & & & 300 & 225 & & & 160 & 120 & 300 & 230 & 300 & 225 \\
\hline Fertiliser 4 product & & & $30-0-0$ & $30-0-0$ & & & & & $30-0-0$ & $30-0-0$ & $30-0-0$ & $30-0-0$ \\
\hline rate $(\mathrm{kg} / \mathrm{ha})$ & & & 300 & 225 & & & & & 300 & 230 & 300 & 225 \\
\hline $\begin{array}{l}\text { Herbicide (pre-em) } \\
\text { product }\end{array}$ & & & Liberator & Liberator & & & & & $\begin{array}{l}\text { Katamaran } \\
\text { turbo }\end{array}$ & $\begin{array}{l}\text { Katamaran } \\
\text { turbo }\end{array}$ & Liberator & Liberator \\
\hline rate (per ha) & & & $0.6 \mathrm{~L}$ & $0.3 \mathrm{~L}$ & & & & & $2.5 \mathrm{~L}$ & $1.25 \mathrm{~L}$ & $0.6 \mathrm{~L}$ & $0.3 \mathrm{~L}$ \\
\hline $\begin{array}{l}\text { Herbicide (post-em) } \\
\text { product }\end{array}$ & $\begin{array}{r}\text { Stomp, Artist, } \\
\text { Reglone, Shark }\end{array}$ & $\begin{array}{l}\text { Reglone, } \\
\text { Shark }\end{array}$ & $\begin{array}{l}\text { Traton SX, } \\
\text { Charge }\end{array}$ & $\begin{array}{l}\text { Traton SX, } \\
\text { Charge }\end{array}$ & Stomp & Stomp & $\begin{array}{l}\text { Traton SX, } \\
\text { Charge }\end{array}$ & Headland spruce & Panarex & Panarex & $\begin{array}{l}\text { Traton SX, } \\
\text { Charge }\end{array}$ & $\begin{array}{l}\text { Tomahawk } \\
\text { Charge }\end{array}$ \\
\hline rate (per ha) & $\begin{array}{c}2.9 \mathrm{~L}, 2.5 \mathrm{~kg}, 2 \mathrm{~L} \\
0.3 \mathrm{~L}\end{array}$ & $2 \mathrm{~L}, 0.3 \mathrm{~L}$ & $0.04 \mathrm{~kg}, 1 \mathrm{~L}$ & $0.04 \mathrm{~kg}, 1 \mathrm{~L}$ & $3 \mathrm{~L}$ & $1.65 \mathrm{~L}$ & $30 \mathrm{~g}, 1 \mathrm{~L}$ & $4.5 \mathrm{~L}$ & $1 \mathrm{~L}$ & $1 \mathrm{~L}$ & $0.045 \mathrm{~kg}, 1 \mathrm{~L}$ & $0.045 \mathrm{~kg}, 1 \mathrm{~L}$ \\
\hline Harvest & Sep-Oct & Sep-Oct & Sep (straw baled) & $\begin{array}{c}\text { Sep (straw } \\
\text { chopped and } \\
\text { incorporated) }\end{array}$ & Sep-Oct & Sep-Oct & $\begin{array}{c}\text { Aug-Sep } \\
\text { (straw baled) }\end{array}$ & $\begin{array}{l}\text { Aug-Sep (straw } \\
\text { chopped and } \\
\text { incorporated) }\end{array}$ & Aug & Aug & $\begin{array}{l}\text { Aug (straw } \\
\text { baled) }\end{array}$ & $\begin{array}{c}\text { Aug (straw } \\
\text { chopped and } \\
\text { incorporated) }\end{array}$ \\
\hline
\end{tabular}


The integrated system aims to maintain yields, enhance biodiversity and reduce non-renewable inputs and losses from the system relative to conventional practice (Table 1). The key targets for management are soil biophysical properties, plant nutrient supply, crop protection and arable biodiversity. Good soil physical structure is important in optimizing plant rooting characteristics and reducing losses through erosion, runoff and leaching. To increase soil organic matter, improve physical structure and reduce soil disturbance, the integrated system included cover cropping over winter, cereal straw incorporation, municipal green waste compost amendments (at $35 \mathrm{tha}^{-1}$ ) and conservation (non-inversion tillage).

Mineral nitrogen $(\mathrm{N})$ fertilizer inputs have the biggest impact on the environmental footprint of arable production systems compared to most other farming practices [18]. At the CSC, reliance on mineral $\mathrm{N}$ is reduced by minimizing losses of plant nutrients (through improved soil structure and cover cropping), maximizing resource uptake and use efficiency by the crop (through improved soil structure, crop variety choice and intercropping), and supplementing with alternative renewable sources of $\mathrm{N}$ through inputs of green manure and Biological Nitrogen Fixation by legumes (clover) under-sown in the spring barley crops.

Finally, crop protection inputs (primarily herbicides) were reduced and modified to enhance within-field biodiversity and increase the resources available to arable food webs. The weed management strategy was to target pernicious grass weeds but allow an understorey of dicot weeds as a resource for beneficial insects. Field margins around the integrated treatments were sown with a species rich mix to encourage pollinators and natural enemies of crop pests as part of an overall Integrated Pest Management strategy.

The composite treatments that make up both cropping systems are sufficiently flexible to respond to nutrient and crop protection issues as they arise and to track changes in regulations and standard commercial practice over time.

\subsection{Sampling Methods}

Key indicators of the arable cropping system were measured each growing season as described in References $[15,16]$. Here we focus on the plant responses: within field weed seedbank, emerged weed flora and crop yields.

\subsubsection{Soil and Weed Seedbank}

Soil samples were collected in March 2011 and then at the same time every year for the first six-year rotation. Samples were taken from each of 350 permanent GPS sample locations across the six fields (Figure 1). At each sample position, $1.5 \mathrm{~L}$ of soil was taken to a depth of $0.15 \mathrm{~m}$ using a soil auger or trowel, weighed and passed through a sieve with a mesh size of $10 \mathrm{~mm}$. Stones exceeding $10 \mathrm{~mm}$ in diameter were removed. About $1.2 \mathrm{~L}$ of the sieved sample was placed in a $15 \times 21 \mathrm{~cm}$ plastic tray to a depth of $40 \mathrm{~mm}$ for weed seedling emergence assessments. Sub-samples of the remaining soil were sieved to $1 \mathrm{~mm}$ and analysed for a range of properties: $\mathrm{pH}$ for each sample was measured from $20 \mathrm{~mL} 0.01 \mathrm{M}$ solution of calcium chloride in $10 \mathrm{~g}$ soil; available phosphorus (P) was measured using the Olsen method [19]; available potassium (K) was extracted with ammonium nitrate and the solution was measured with adsorption flame photometry [19]. The remainder of the soil from each sample was dried at $70^{\circ} \mathrm{C}$ for $24 \mathrm{~h}$. A subsample of dried soil from each location was then milled and weighed for analysis of organic carbon and total nitrogen using an Exeter Analytical CE440 Elemental Analyser (EAI, Coventry, UK). The rest of the dried soil was archived as reference material for future research projects. Complete datasets for all soil chemical analyses are only available for 2013 so, for the purposes of this paper, Principal Components Analysis (using a correlation matrix) of the soil data is restricted to this sampling year.

The seed trays for weed emergence assessments were arranged randomly in an unheated glasshouse on benches fitted with capillary matting, which was kept moist via an overhead automatic misting system. Seedlings were identified to species where possible, recorded and removed as they emerged. 
The volume and depth of soil and the general conditions for emergence, were similar to those in historical studies [20-22] and more recent assessments carried out in this laboratory [23-25]. The first flush of seedlings was considered complete after about 18 weeks, when there was no further emergence for a period of 14 days. The soil was then re-sieved, placed back in the seed trays and the procedure repeated for a second flush of emergence following a winter chill (ambient winter conditions with a minimum of two weeks at $0^{\circ} \mathrm{C}$ or below), to encourage the germination of any remaining viable seeds from each sample. The total number of weed seedlings per species per sample was converted to number per $\mathrm{m}^{2}$ field surface to a depth of $0.15 \mathrm{~m}$. Here we focus on total densities of monocotyledonous and dicotyledonous weeds as these categories represent different resource qualities to invertebrate food webs [26] and herbicide targets for weed control within cereal and broadleaved crops [4].

\subsubsection{Emerged Weed and Crop Biomass Production}

To test for likely biodiversity gains and the potential for a negative competitive interaction between in-field weeds and crop yield, total above-ground plant biomass was sampled in late July of each growing season, just before weed senescence during the month before the main cereal harvest period. All above-ground weed and crop plant material was sampled from within $0.5 \times 1 \mathrm{~m}$ quadrats at three of the five permanent GPS locations in each cultivar strip and treatment (Figure 1), providing 210 samples across the site in total. Potato plants were not included in the biomass sampling as the harvestable biomass in this crop is allocated below ground. Analysis was restricted to crops with above-ground yielding material.

Plant material from each sample was divided into four categories: (i) crop stems (from soil surface level to ear); (ii) crop grain (cereal crop ears, not threshed) or pods (oilseed rape and bean pods, stripped from stems, not threshed); (iii) monocot weeds; and, (iv) dicot weeds. These four sets of samples from each sample location were dried at $70{ }^{\circ} \mathrm{C}$ for $24 \mathrm{~h}$ and weighed for an estimate of above ground biomass production.

\subsubsection{Crop Yields}

Yields of cereals, beans and oilseed crops of each cultivar were taken from the yield meter on the combine at harvest, calibrated for each crop and field using the weigh scale on the trailer. Total weight taken off each $18 \mathrm{~m}$ strip, not including headland, was converted to tonnes per hectare and adjusted to $14 \%$ moisture content. Potato yields were estimated as fresh matter per cultivar strip and again, converted to tonnes per hectare.

\subsubsection{Statistical Analysis}

A linear mixed model framework was used for each of the experimental datasets as detailed below. All analyses were performed using Restricted Maximum Likelihood (REML) procedures in GenStat for Windows 17th edition (VSN International Ltd., Hemel Hempstead, UK).

Soil and Weed Seedbanks

The fixed effects here were the cropping system and pre-crop as well as any interaction between these. The random effects for the field layout were modelled with a nested structure Field/Field_Half/Strip/Locus where '/' indicates nesting and 'Locus' represents the GPS sample location. In addition, Year was included as a random effect along with its interaction with each of the field layout terms. Given the repeated sampling from the same GPS points each year, care was taken to account for this potential source of temporal correlation. Covariance models with order 1 auto-regression (AR1) were considered for each of the interaction terms of Year with the layout factors at the level of Field, Field Half, Strip and Locus and the final model selected on the basis of improved fit (determined by the deviance) and impact on estimated standard errors of difference of fixed effects. Where these AR1 terms (e.g., for the temporal element of the Field.Field_Half.Year interaction) were included, the corresponding layout effect (e.g., Field.Field_Half) was omitted from 
the random model to avoid estimation and identifiability issues due to aliasing. For monocot weeds, a covariance structure to allow for temporal correlation in the Year.Field interaction was found to be of importance. For dicot weeds, two covariance structures were fitted to allow for temporal correlation in the Year.Field and Year.Field_Half interactions. No covariance structures were found to improve the model for total weed abundance. The response variables were all transformed with inverse hyperbolic sine to stabilise the variance.

\section{Emerged Weed and Crop Biomass Production}

The fixed terms of interest in this analysis were Treatment, Crop and their interaction. The random terms followed the same approach as for the seedbanks. For the crop biomass analyses, potato was removed since there were no measurements. For the weed biomass analyses, both potato and winter barley samples were removed since the measurements in the conventional field halves were almost completely zero.

A mixed model was also used to investigate the relationship between crop biomass and weed biomass. Here, fixed effects were crop, management practice, total weed biomass and all their interactions. Since there was again the issue of repeated sampling from the same sampling locations, covariance structures were fitted as above to account for this. However, none of these meaningfully changed the inferences of the model and did not lead to estimates of AR(1) correlations which were of substantial enough size to warrant inclusion. Hence the model used had no AR(1) correlation terms estimated. The response variables were again all transformed with inverse hyperbolic sine to stabilise the variance.

Yield

Yield was analysed for each crop separately. Analysis of yield had a simpler model since there was only one measurement for each strip. The fixed model terms were crop variety and management practice. The random terms accounted for the nested structure of the field layout: Year/Field_Half/Strip. The Year term represented a confounded term of year and field effect since a crop is grown in only one field in a single year.

\section{Results}

\subsection{Arable Weed Seedbank}

The effect of cropping system and previous crop on the total number of monocot and dicot weed seeds in the seedbank is shown in Figure 2. REML analysis showed that the effect of previous crop on monocot seedbank densities was significant $(p=0.017)$ and although the treatment effect was non-significant $(p=0.267)$, there was a significant interaction between treatment and previous crop $(p=0.017)$. This was mainly due to the large difference between integrated and conventional management following winter wheat. The next largest difference between treatments was following spring beans but there was no evidence for any difference between management treatments in any of the other crops.

Integrated crop management had an overall positive effect on the estimated density of dicot weeds in the seedbank $(p=0.023)$. Previous crop also had a significant effect on the subsequent seedbank density $(p=0.038)$ : the greatest dicot densities were detected after spring beans and the smallest following winter barley, reflecting differences in emerged weed biomass between crops. There was also significant interaction between treatment and previous crop $(p=0.002)$ : integrated management had a much greater positive effect on the density of dicot weed seeds following winter oilseed rape compared to winter barley, where there was no effect of cropping system on dicot seed density. 


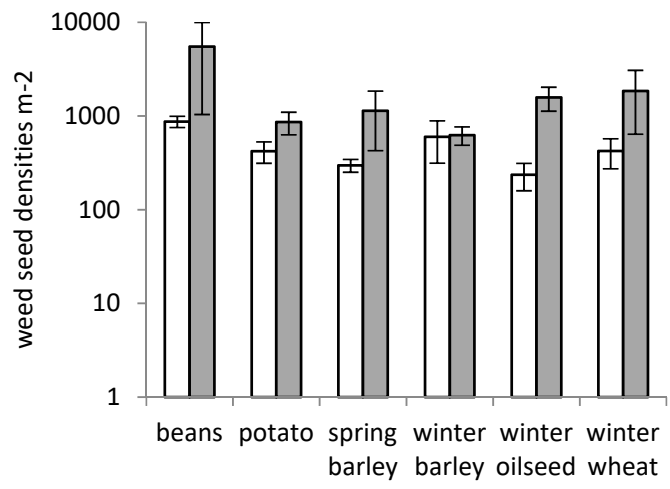

(a)

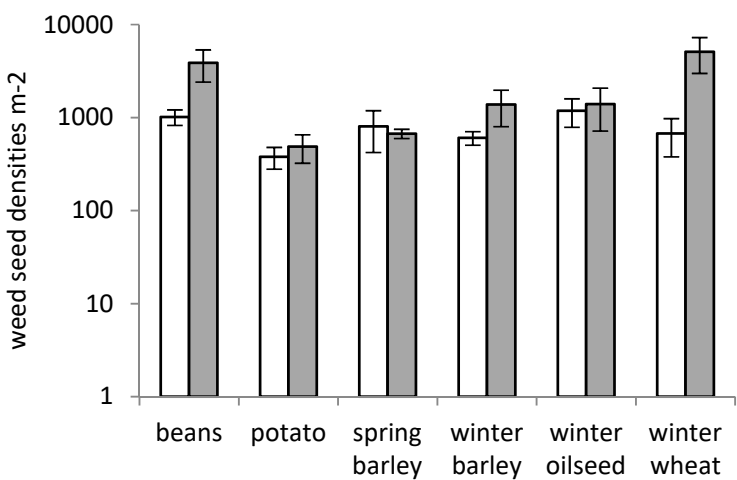

(b)

Figure 2. Effect of previous crop type and cropping system (conventional (open bars) and integrated (solid bars) management) on densities of (a) monocot and (b) dicot weed seeds in the seedbank. Data are mean values $\mathrm{m}^{-2}$ (and standard errors on variation between years) over the first six-year rotation.

\subsection{Soil}

Principal components analysis (using the correlation matrix) of soil $\mathrm{pH}$, potassium, phosphorus, $\%$ carbon, \% nitrogen and loss on ignition from 2013 samples (Table 2) gave clear separation on the first axis between conventional and integrated management for each of the fields (Figure 3). This separation was driven by greater soil concentrations of all variates $(\% \mathrm{~N}, \% \mathrm{C}, \mathrm{K}$ and organic matter) in the integrated management system relative to the conventional treatment. Loadings on PC1 were between 0.3 and 0.45 for all variates except phosphorus, which was more strongly associated with axis 2 (loading of 0.7 ).

Table 2. Differences between conventional and integrated field halves in the soil properties used as input variables for the principal components analysis presented in Figure 3. Soil samples were taken in March 2013, sample number $=350$.

\begin{tabular}{|c|c|c|c|c|c|c|c|}
\hline & & $\% \mathrm{C}$ & $\% \mathbf{N}$ & Loss on Ignition $\left(450^{\circ} \mathrm{C}\right)$ & $P\left(\mathrm{mg} \mathrm{kg}^{-1}\right)$ & $\mathrm{K}\left(\mathrm{mg} \mathrm{kg}^{-1}\right)$ & $\mathrm{pH}$ \\
\hline \multirow{2}{*}{ Road (K) } & conventional & 1.76 & 0.16 & 3.9 & 87.72 & 140.1 & 5.44 \\
\hline & integrated & 2.58 & 0.22 & 5.4 & 90.68 & 234.4 & 5.68 \\
\hline \multirow{2}{*}{ Mid-east (L) } & conventional & 1.74 & 0.16 & 3.9 & 77.27 & 134.0 & 5.45 \\
\hline & integrated & 2.31 & 0.19 & 4.4 & 77.99 & 203.3 & 5.68 \\
\hline \multirow{2}{*}{ Den South (M) } & conventional & 2.49 & 0.20 & 5.7 & 46.97 & 94.68 & 5.35 \\
\hline & integrated & 2.71 & 0.24 & 5.9 & 53.81 & 149.8 & 5.36 \\
\hline \multirow{2}{*}{ Pylon (N) } & conventional & 3.15 & 0.28 & 7.2 & 49.28 & 209.7 & 5.46 \\
\hline & integrated & 4.54 & 0.41 & 10.1 & 62.86 & 467.6 & 5.71 \\
\hline \multirow{2}{*}{ Kennels (O) } & conventional & 2.80 & 0.24 & 6.3 & 73.23 & 152.7 & 5.53 \\
\hline & integrated & 3.87 & 0.33 & 8.5 & 69.44 & 401.6 & 5.64 \\
\hline \multirow{2}{*}{ Estate (P) } & conventional & 2.88 & 0.25 & 6.8 & 47.60 & 190.0 & 5.53 \\
\hline & integrated & 4.33 & 0.39 & 9.8 & 79.14 & 507.7 & 5.82 \\
\hline
\end{tabular}

\subsection{Weed and Crop Biomass}

Dry weights $\left(\mathrm{g} \mathrm{m}^{-2}\right)$ of crop stems and grain and monocot and dicot weeds for each crop are shown in Table 3 and the output from the REML analysis (data inverse hyperbolic sine transformed) in Figure 4. Potato and winter barley are not included in this analysis as potato above-ground biomass was not sampled and conventional winter barley fields had no weeds to compare against the integrated treatments. 


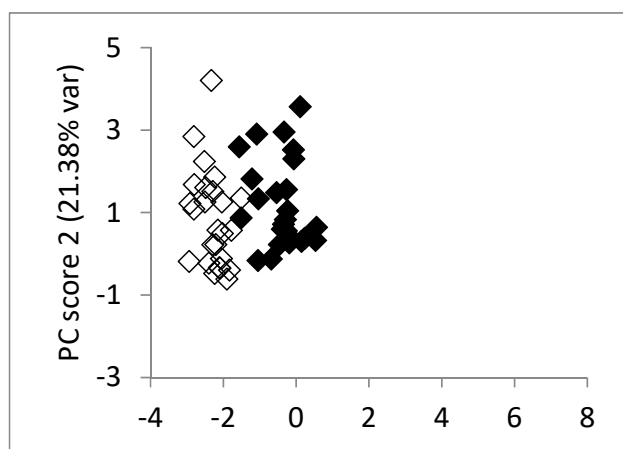

(a)

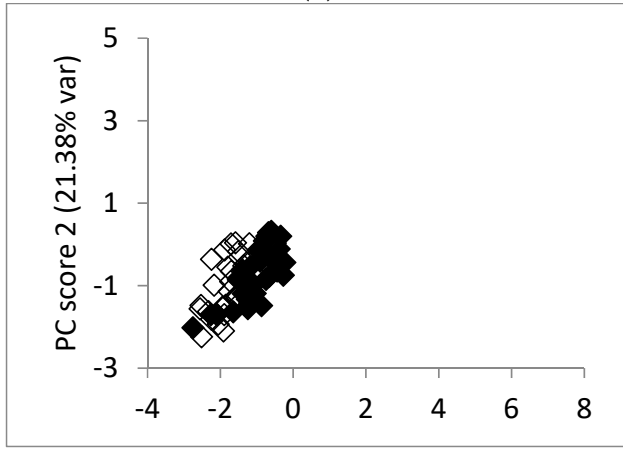

(c)

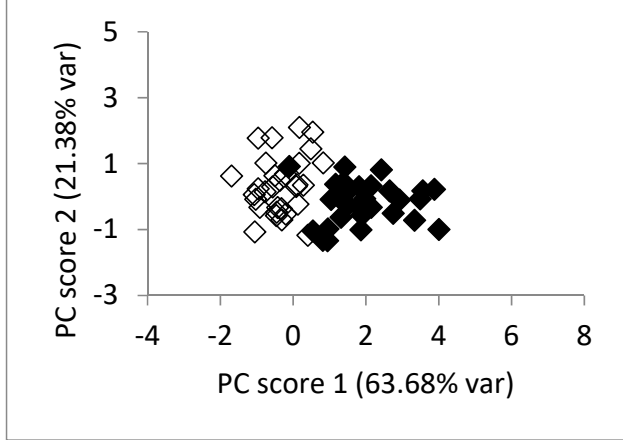

(e)

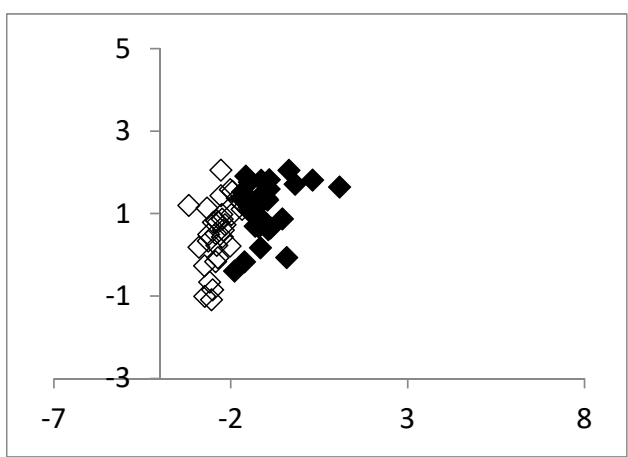

(b)

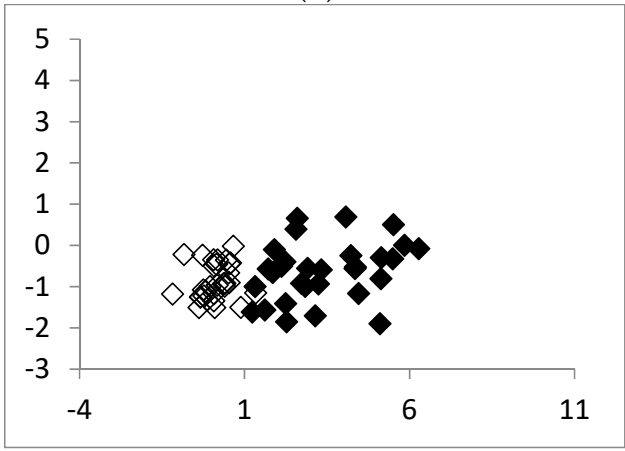

(d)

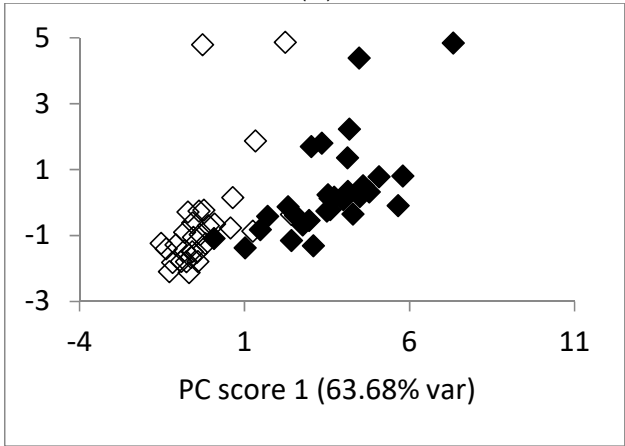

(f)

Figure 3. Principal component scores for soil chemistry variates $(\% \mathrm{~N}, \% \mathrm{C}, \mathrm{DOM}, \mathrm{P}, \mathrm{K}, \mathrm{pH})$ sampled in March 2013 under integrated (closed symbols) and conventional (open symbols) management in each of CSC platform fields (a) Field K, sown winter oilseed, (b) Field L, sown winter wheat, (c) Field M, conventional ploughed, integrated stubble, (d) Field N, sown winter barley, (e) Field O, stubble, (f) Field P, stubble.

Table 3. Median above ground weed and crop biomass $\left(\mathrm{g} \mathrm{m}^{-2}\right)$ sampled in July each year under integrated (integ) and conventional (conv) cropping systems. Sample number $=108, \mathrm{n} / \mathrm{a}=$ not applicable (samples not collected).

\begin{tabular}{ccccccccc}
\hline & \multicolumn{2}{c}{ Dicot } & \multicolumn{2}{c}{ Monocot } & \multicolumn{2}{c}{ Stems } & \multicolumn{2}{c}{ Pod/Ear } \\
\cline { 2 - 9 } & conv & integ & conv & integ & conv & integ & conv & integ \\
\hline Potato & 0 & 13.45 & 0 & 2.52 & $\mathrm{n} / \mathrm{a}$ & $\mathrm{n} / \mathrm{a}$ & $\mathrm{n} / \mathrm{a}$ & $\mathrm{n} / \mathrm{a}$ \\
Winter wheat & 0.7 & 0.6 & 23.8 & 46.1 & 547.4 & 460.2 & 781.6 & 593.2 \\
Beans & 2.8 & 26.1 & 3.9 & 36.4 & 324.3 & 359.5 & 499.1 & 584.6 \\
Spring barley & 0.4 & 21.2 & 4.9 & 12.9 & 524.5 & 404.2 & 564.8 & 527.4 \\
Winter oilseed & 3.1 & 12.7 & 0.6 & 1.1 & 657.4 & 673.8 & 501.8 & 530 \\
Winter barley & 0 & 0 & 0 & 0.5 & 835.3 & 848.6 & 620.2 & 504.2 \\
\hline
\end{tabular}




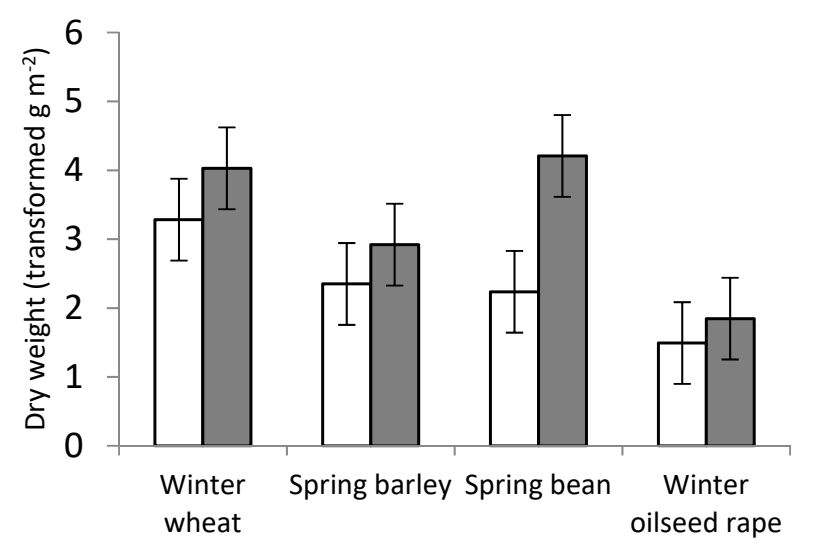

(a)

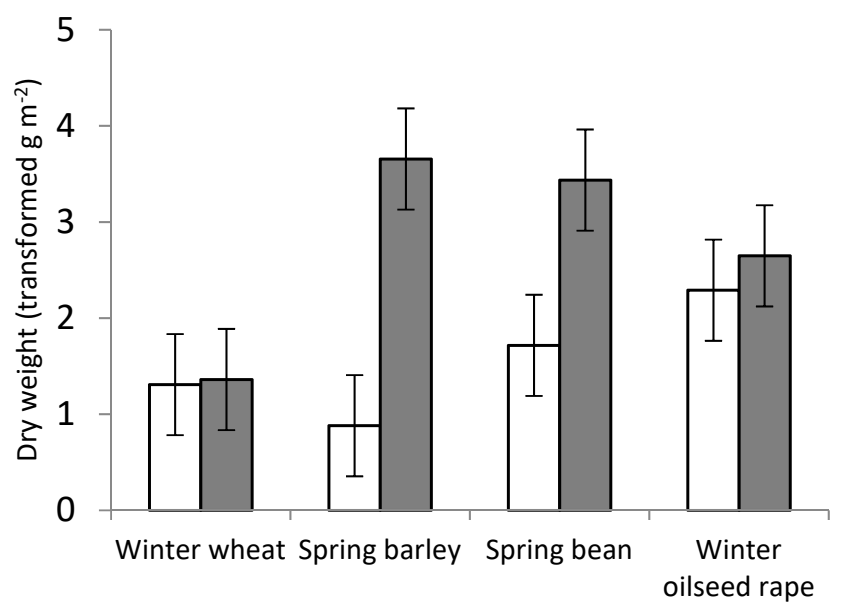

(b)

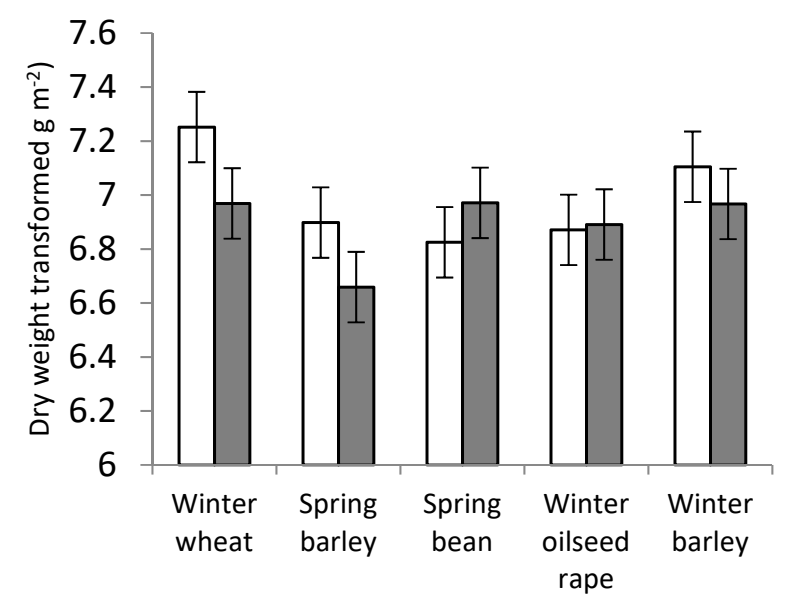

(c)

Figure 4. Cont. 


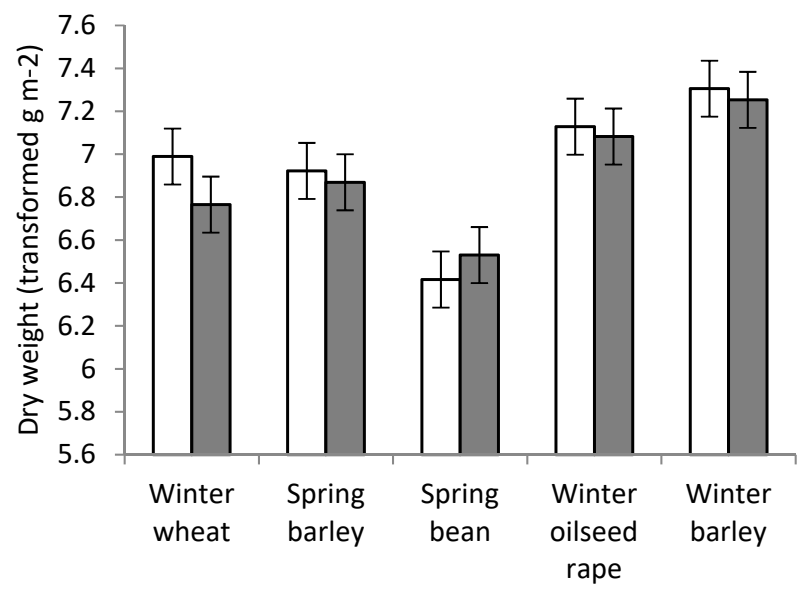

(d)

Figure 4. Dry weights of (a) monocot weeds, (b) dicot weeds, (c) crop stems and (d) crop grain/pods under conventional (open bars) and integrated (solid bars) treatments. Data are mean values $\mathrm{m}^{-2}$ (and standard errors) estimated from REML model over the first six- year crop rotation, transformed with inverse hyperbolic sine.

Monocot weed mass was significantly greater in the integrated management system (average across all crops of $40 \mathrm{~g} \mathrm{~m}^{-2}$ compared to $16 \mathrm{~g} \mathrm{~m}^{-2}$ under conventional management, $p=0.04$ ). There were also significant differences in weed mass between crops $(p=0.04$, Figure 4$)$ but no significant interaction between crop and treatment. Dicot weed mass was also significantly greater under the integrated management system (average of $20 \mathrm{~g} \mathrm{~m}^{-2}$ compared to $9 \mathrm{~g}^{-2}$ in the conventional treatment, $p=0.016$, Figure 4) and, although there was no main effect of crop for this weed group, there was an interaction between crop and treatment $(p<0.001)$ : the spring sown crops had much greater mass of dicot weeds in the integrated compared to conventional management system than did the winter sown crops.

REML analysis of crop stem mass taken at the same time as the weed mass showed a significant effect of management treatment $(p=0.041)$ and interaction with crop type $(p=0.005)$. This interaction was driven by the cereal crops (winter wheat, spring and winter barley) having a greater stem mass in conventional treatments. By contrast, stem mass of beans was greater under integrated management and winter oilseed rape showed no difference between the management practices. Crop grain mass was significantly different between crop types $(p=0.02)$ but there was no effect of management treatment.

A mixed model was fitted to assess the likelihood of competitive interaction between crop and weeds under the two management systems. Total crop mass showed a significant negative relation with total weed mass $(p<0.001)$, with a slope of 0.049 (s.e. $=0.007$ ). There was also a significant interaction between crop and treatment $(p=0.013)$. No evidence was detected for interactions between total weed mass and crop or management practice. (A model with separate terms for monocot and dicot mass was fitted initially but found very similar slopes and so a simpler model with total weed mass was preferred.)

\subsection{Crop Yields}

Yield averages across years for each crop are shown in Figure 5. Only bean yields showed no significant differences amongst varieties, management practices or their interaction. REML analysis of potatoes, spring barley, winter oilseed rape and winter barley all showed significant differences in yield between varieties (Table 4) but no effect of management treatment, nor any interaction between them. Only winter wheat yield was significantly affected by cropping system, with conventional management producing an average of $9.5 \mathrm{tha}^{-1}$ compared to $7.2 \mathrm{tha}^{-1}$ from the integrated system ( $p=0.001$, Figure 5$)$. There was also a significant difference between the five varieties of winter wheat and an interaction between variety and treatment (Table 4), where some varieties (e.g., Viscount) showed a stronger negative effect of the integrated management system on yield than others (e.g., Beluga). 


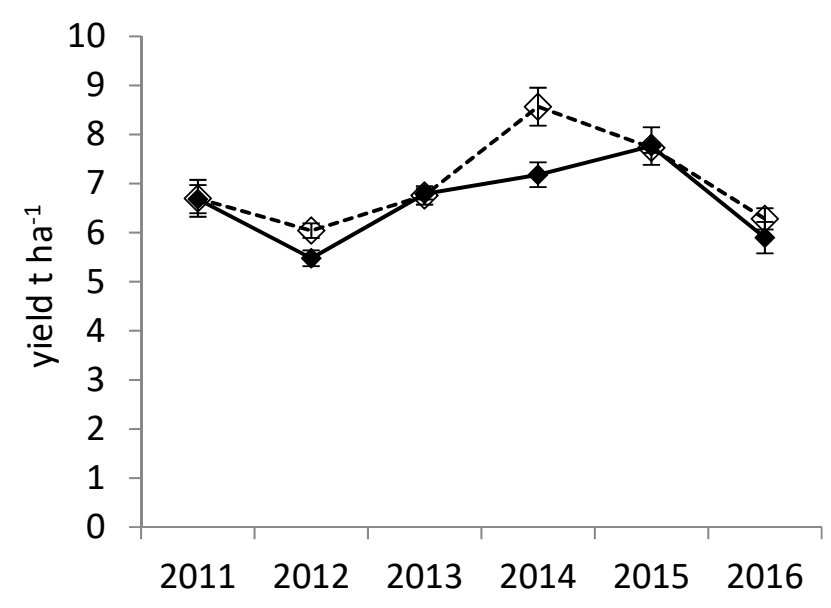

(a)

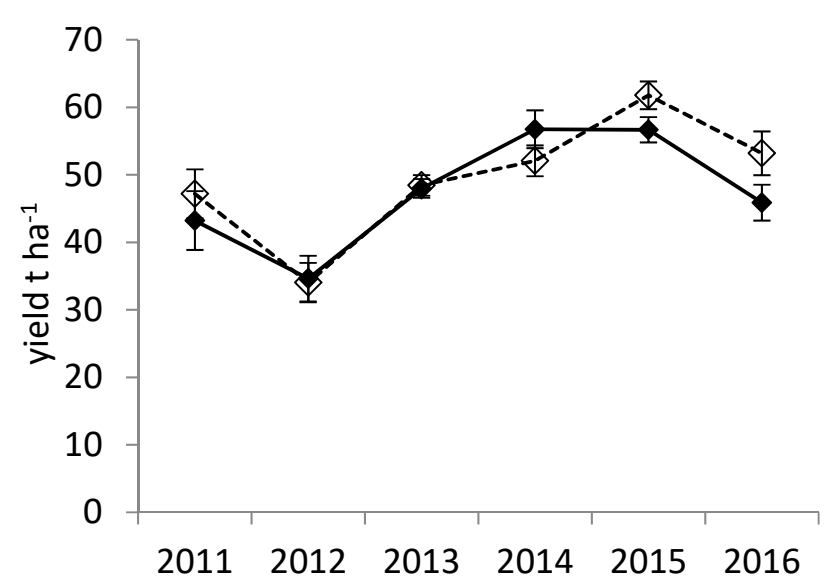

(b)

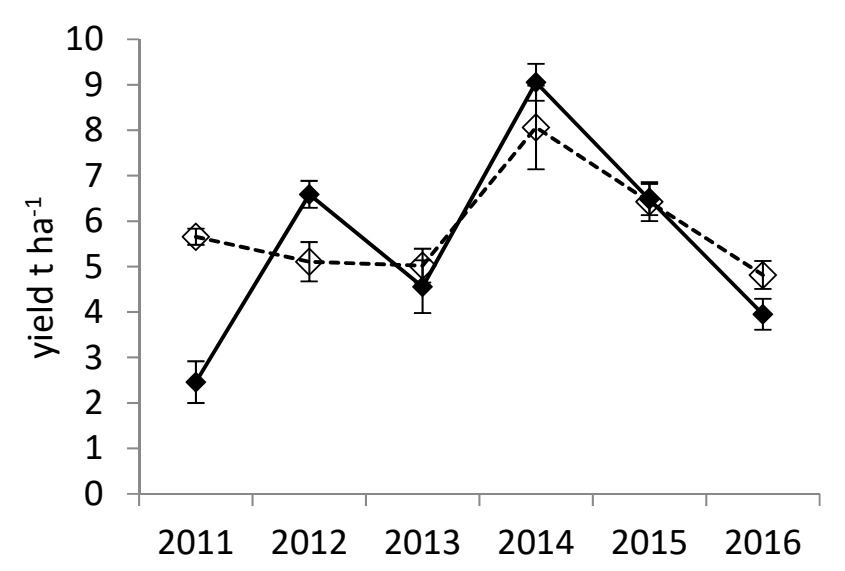

(c)

Figure 5. Cont. 


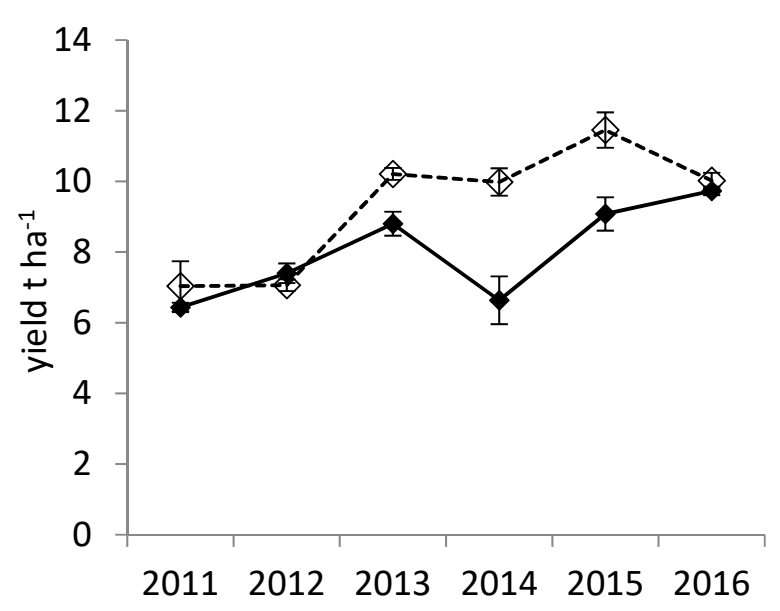

(d)

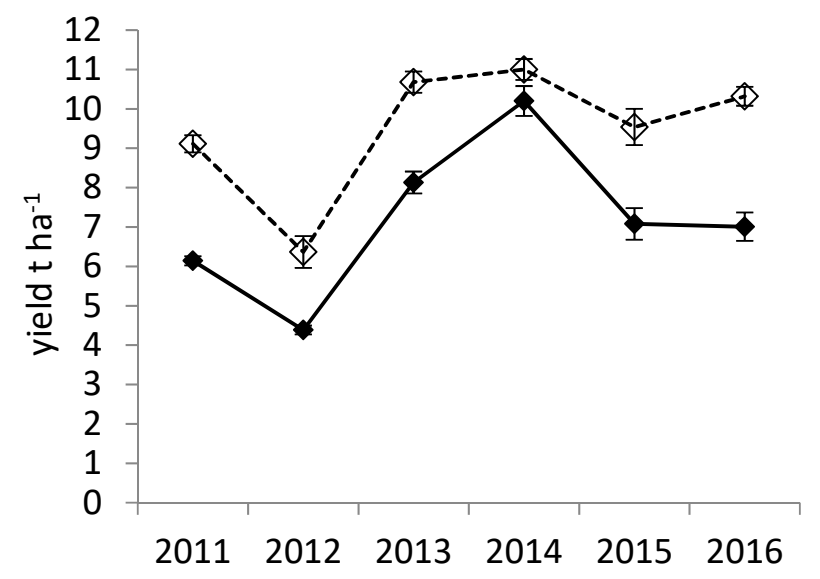

(e)

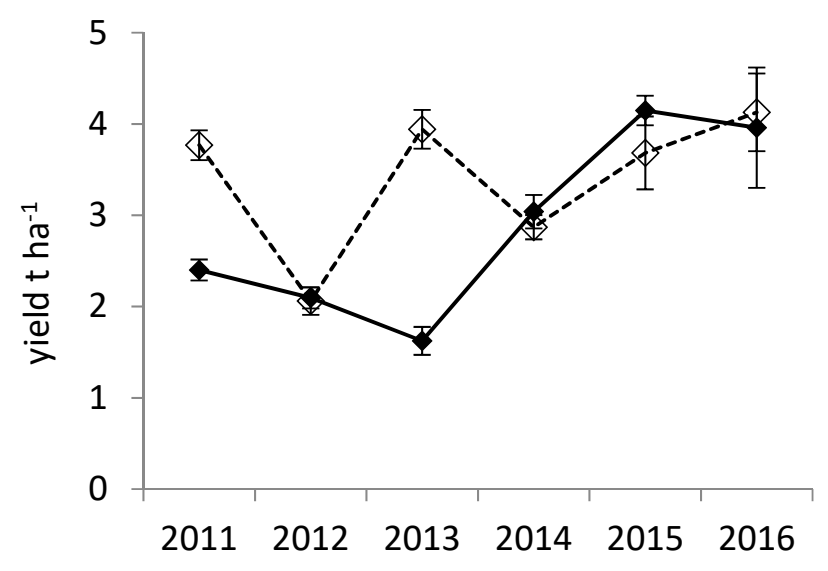

(f)

Figure 5. Crop yield responses to conventional (dotted line, open symbols) and integrated (solid line, closed symbols) cropping systems. Data are mean values for yield $\left(\mathrm{t} \mathrm{ha}^{-1}\right)$ with standard errors of between-variety variation for each year of the first six year crop rotation. (a) spring barley (ns = not significant), (b) potato (ns), (c) field beans (ns), (d) winter barley (ns), (e) winter wheat $(p<0.001)$, (f) winter oilseed rape (ns). 
Table 4. Mean yields across years for each crop variety with standard errors and probability values from REML (Restricted Maximum Likelihood) analysis.

\begin{tabular}{|c|c|c|c|c|c|c|c|}
\hline Crop & Variety & Integrated & Conventional & S.E. & F pr var & F pr tmt & F pr inter \\
\hline \multirow[t]{8}{*}{ Field beans } & Maris Bead & 6.62 & 6.16 & 0.99 & 0.12 & 0.65 & 0.78 \\
\hline & Boxer & 6.22 & 5.53 & & & & \\
\hline & Fanfare & 6.04 & 5.66 & & & & \\
\hline & Fuego & 5.97 & 6.20 & & & & \\
\hline & Pyramid & 5.28 & 6.00 & & & & \\
\hline & Babylon & 5.09 & 5.38 & & & & \\
\hline & Ben & 4.92 & 5.58 & & & & \\
\hline & Tattoo & 3.67 & 5.35 & & & & \\
\hline \multirow[t]{5}{*}{ Potatoes } & Lady Balfour & 54.29 & 53.74 & 3.76 & $<0.001$ & 0.31 & 0.7 \\
\hline & Maris Piper & 48.33 & 49.55 & & & & \\
\hline & Vales Sovereign & 47.80 & 51.45 & & & & \\
\hline & Cabaret & 45.54 & 50.12 & & & & \\
\hline & Mayan Gold & 37.69 & 39.70 & & & & \\
\hline \multirow{5}{*}{ Spring barley } & Concerto & 7.38 & 7.34 & 0.41 & $<0.001$ & 0.16 & 0.58 \\
\hline & Waggon & 6.96 & 7.29 & & & & \\
\hline & Westminster & 6.50 & 6.95 & & & & \\
\hline & Optic & 6.34 & 6.71 & & & & \\
\hline & Variety mixture & 6.28 & 6.99 & & & & \\
\hline \multirow{5}{*}{ Winter barley } & Retriever & 8.69 & 9.84 & 0.72 & $<0.001$ & 0.06 & 0.22 \\
\hline & Sequel & 8.26 & 9.38 & & & & \\
\hline & Variety mixture & 8.12 & 9.02 & & & & \\
\hline & Saffron & 7.58 & 9.59 & & & & \\
\hline & Cassata & 6.96 & 8.86 & & & & \\
\hline \multirow{5}{*}{ Winter wheat } & Viscount & 10.38 & 6.83 & 0.79 & 0.04 & 0.001 & 0.004 \\
\hline & Istabraq & 9.63 & 7.26 & & & & \\
\hline & Consort & 9.51 & 7.04 & & & & \\
\hline & Beluga & 9.29 & 8.08 & & & & \\
\hline & Alchemy & 8.85 & 6.93 & & & & \\
\hline \multirow{6}{*}{ Winter rape } & Catana & 3.46 & 3.95 & 0.48 & 0.001 & 0.30 & 0.96 \\
\hline & Flash & 2.97 & 3.45 & & & & \\
\hline & NK Grace & 2.85 & 3.29 & & & & \\
\hline & Excalibur & 2.73 & 3.10 & & & & \\
\hline & Lioness & 2.65 & 3.35 & & & & \\
\hline & Cracker & 2.19 & 3.03 & & & & \\
\hline
\end{tabular}

\section{Discussion}

The aim of the CSC long-term platform is to iteratively develop an integrated cropping system that improves on overall (economic and environmental) sustainability relative to conventional management [16]. In intensive crop production systems, arable biodiversity and environmental footprint are usually sacrificed to maximise yields and economic returns for farm businesses. The integrated management system implemented here specifically aimed to benefit biodiversity and environmental health by reducing agrochemical inputs and minimize the impact that this might have on crop yield. This was achieved by incorporating alternative management practices (conservation tillage, organic carbon amendments, integrated pest and weed management, cover crops and legume intercrops) into a single cropping system. Over the first six-year rotation, integrated management incurred no yield penalty except in winter wheat. There was no evidence for a build-up of competitive grass weeds in the seedbank but there was a positive impact on the abundance of broadleaved weeds. In general, these dicotyledonous weeds represent better value resource for beneficial invertebrates than do grass weeds and therefore support the processes required for healthy agroecosystem function [25,27]. Even though soil data were only available for the third year of the six-year rotation, $\mathrm{pH}$, soil carbon content and concentrations of the main plant nutrients were all improved after just three years of integrated management relative to the conventional treatment. The integrated management system was therefore largely successful in fulfilling the overall objectives of maintaining yield with lower inputs and enhancing environmental health and biodiversity. These results are disseminated to the 
farming community and industry organizations through web material, industry events, farm tours and demonstrations at public events where feedback from stakeholders on management options, directions, strategies and risks are encouraged for future development of the platform.

The first six-year rotation was the establishment phase of the long-term platform where the cropping systems were put in place and monitoring protocols for key system indicators were tested [16]. Analyses of the responses of each variable and the interactions between them are then used to refine the components of the integrated management system to improve on the overall levels of biodiversity and system sustainability in subsequent rotations. Although the results presented here suggest that the management system was generally successful in terms of plant responses, some areas can be identified for improvement.

Winter wheat yields were consistently lower under the integrated management system relative to conventional practice. Winter wheat is generally an intensively managed crop, receiving high fertilizer inputs and rigorous weed control to maximise yields. The data presented here suggest that the yield loss in the integrated cropping system is unlikely to be due to competition for resources with the weed flora: the effect was evident from year 1 before any build-up of treatment differences in weed densities and the negative relation between wheat mass and dicot weed mass was weaker than for other crops where no significant yield penalty was observed. Winter wheat yields were therefore more likely to be a response to the lower rate of applied mineral nitrogen, due to traditional breeding and selection of varieties that perform well under high nutrient conditions: for example, compare the difference in treatment response of high yielding varieties (e.g., Viscount) with the lower yielding cultivars (e.g., Beluga) in Table 4. The average application of nitrogen (N) was $183 \mathrm{~kg} \mathrm{ha}^{-1}$, of which, assuming $1.6 \% \mathrm{~N}$ in grain for feed and alcohol production, $160 \mathrm{~kg} \mathrm{ha}^{-1}$ would be taken up in a grain yield of $10 \mathrm{t} \mathrm{ha}^{-1}$ (Figure 5). An additional amount would be removed as straw, accounting for most of that applied. Reducing mineral $\mathrm{N}$ input to $75 \%$ or $135 \mathrm{t} \mathrm{ha}^{-1}$ would mean that yield in the integrated treatment would fall below that of the conventional, unless $\mathrm{N}$ had become available from other sources, which appears not to have been the case to date. The other winter cereal was not put under such pressure in the integrated treatment because it yielded less and has lower grain \% $\mathrm{N}$ but even so, the integrated treatment fell below the conventional in three of the six years. Adjustment of nitrogen budgeting will therefore be needed to ensure that winter cereals under integrated management yield the same as those under conventional.

To define the most cost-effective and sustainable nutrient management strategy, detailed examination of the nitrogen balance through the rotation will be carried out. Straw incorporation, green waste compost amendments, cover-cropping and non-inversion tillage have resulted in increases in soil organic matter, phosphorus, potassium and $\mathrm{pH}$ in the integrated management treatment. Percentage nitrogen was also greater in the integrated system, although not sufficient in plant available form to compensate for the reductions in mineral nitrogen fertilizer inputs to winter wheat. A more sustainable approach would be to determine $\mathrm{N}$ input according to soil nutrient supply, thereby lowering the risk of over application and resulting losses to the environment through greenhouse gas emissions and leaching $[14,28]$. Further refinements could also include replacing mineral fertilizers entirely with renewable sources of plant nutrients such as biogas digestates [29] and atmospheric nitrogen fixed by legumes $[30,31]$ and apply this at a rate determined by soil nutrient levels, aiming to maintain the yields of barley, potatoes and oilseed at current levels and close the yield gap between management treatments in winter wheat.

Apart from soil and nutrient management, another critical component of the arable system for improving sustainability is biodiversity. The benefits of increasing diversity in arable systems, in terms of carbon and nutrient cycling, pollination, predation of crop pests and disease suppression, are now widely acknowledged [4,32]. The basis for this biodiversity within the cropped area is the arable seedbank from which the emerged weed flora regenerates each season (e.g., [25,33]). Management of beneficial weeds at acceptable levels while controlling pernicious weeds through selective herbicide use, without risking a build-up of resistance represents a major agronomic challenge [34]. 
The arable seedbank is influenced by management system and cropping history [26,35]. Greater biomass of above-ground weeds in the integrated management system leads to greater seed return to the seedbank and therefore a build-up of weed seeds over time relative to conventional practice. Careful management of the weed seed return is therefore essential to achieve a balance between provision of resource for farmland wildlife and the generation of a weed seed burden sufficient to affect yields in following crops. There was evidence of a negative association between crop and weed mass when measured in July, although this appeared driven largely by low winter wheat mass in 2012. This was a particularly wet year with poor establishment of this crop, providing opportunity for more weed growth than is normally possible. However, given that there is no detectable management effect on final crop yield for five of the six crops tested, it is likely that weed densities in general are below competition thresholds [36]. Minimal competitive interaction between crop and weed biomass is likely to be due to the observed improvement in soil conditions, providing sufficient resources to allow coexistence between crop and weed plants at the densities observed.

Although there was no evidence for a build-up of grass weeds in the seedbank over the course of the first six-year rotation, some studies have demonstrated increases in the densities of grass weeds in conservation tillage systems [37], although other studies have shown conflicting evidence for the effect of tillage on grass and broadleaved weeds (e.g., [38]). In the current rotation, the integrated system is ploughed every six years for potato production and this may be sufficient to prevent the build-up of competitive weeds in the seedbank, maintaining populations below competition threshold [39]. An unplanted area within the potato field at the CSC has now been put in place to quantify the effect of cultivation period on long-term population trends (over multiple rotations). This will allow comparison of no-till (integrated management with no potatoes) with plough one year in six (integrated management with potatoes) and annual plough (standard conventional practice).

Previous crop is also important in determining the composition and abundance of the seedbank community since timings of soil disturbance events and herbicide applications within the growing season vary considerably according to crop type. Dicot weed densities were greater in the seedbank in the integrated management treatment following all crops except winter barley, whereas monocots were only greater following winter wheat (where grass weeds are difficult to control) and spring beans (where meadow grass can flourish in the relatively long period before canopy closure). There is, therefore, scope for improvement in winter barley (where dicots numbers could be enhanced) and winter wheat and spring beans (where densities of monocots could be reduced). Alternative weed management strategies that allow small populations of beneficial broadleaved weeds without long-term build-up of weed seeds in the seedbank need to be identified [34]. This is a particular challenge where weed management relies on foliar acting graminicides which can quickly build up resistance. Careful timing of cultivations, use of cover cropping as grass weed suppressants and crop varieties bred for competitive traits, all require investigation and the relative costs and benefits will be estimated before inclusion in the integrated cropping system at the CSC long term platform. However, during the first six-year rotation, the abundance of dicot weeds was generally enhanced under the integrated management treatment with little or no impact on yield.

\section{Conclusions}

Analysis of the crop and weed responses to an integrated management system over the first six-year rotation of a long-term experimental platform has demonstrated success with respect to the overall goals to enhance biodiversity and reduce environmental impact without jeopardizing crop yields. Beneficial broad-leaved weeds were more abundant in the integrated management system across all crops whereas grass weeds showed no overall significant response. Crop yield was maintained for five out of the six crops, suggesting a minimal impact on financial margins. Soil carbon, $\mathrm{pH}$ and soil concentrations of the main plant growth-limiting macronutrients were also enhanced under the integrated management system, which may explain the absence of a competitive interaction between crop and weeds for available resources. These results have highlighted the value 
of a long-term, whole-systems approach to sustainability research. The integrated management system will continue to be developed and refined over the coming rotations and data gathered will provide the opportunity to assess whole system responses to a change in management in the long term. Further analyses will be carried out to identify trade-offs between the system components measured at the CSC and to quantify the net economic and environmental costs and benefits of the integrated management system (though see [40]). These whole systems analyses and long-term risk assessments are essential if new, sustainable farming approaches are to be adopted more widely.

Author Contributions: Conceptualization, C.H., G.S.B., P.P.M.I., A.J.K. and G.R.S.; Data curation, M.Y.; Formal analysis, C.H. and C.J.A.; Methodology, C.H.; Validation, G.R.S.

Acknowledgments: This work is funded by the Scottish Government Strategic Research Programme. The authors would also like to thank Susan Mitchell and Lawrie Brown (soil analysis), Gill Banks, Paul Neave and Linda Nell (field sampling), Stuart Wale, John Bennett and Euan Caldwell (crop management).

Conflicts of Interest: The authors declare no conflict of interest. The founding sponsors had no role in the design of the study; in the collection, analyses, or interpretation of data; in the writing of the manuscript and in the decision to publish the results.

\section{References}

1. Bingham, I.J.; Karley, A.J.; White, P.J.; Thomas, W.T.B.; Russell, J.R. Analysis of improvements in nitrogen use efficiency associated with 75 years of barley breeding. Eur. J. Agron. 2012, 42, 49-58. [CrossRef]

2. Knight, S.; Kightley, S.; Bingham, I.; Hoad, S.; Lang, B.; Philpott, H.; Stobart, R.; Barnes, T.J.A.; Ball, B. Desk Study to Evaluate Contributory Causes of the Current 'Yield Plateau' in Wheat and Oilseed Rape; HGCA Project Report 502; HGCA: Stoneleigh, UK, 2012; p. 226.

3. Lipieca, J.; Arvidssonb, J.; Murerc, E. Experiences with the impact and prevention of subsoil compaction in the European Union. Soil Till. Res. 2003, 73, 15-29.

4. Marshall, E.J.P.; Brown, V.K.; Boatman, N.D.; Lutman, P.J.W.; Squire, G.R.; Ward, L.K. The role of weeds in supporting biological diversity within crop fields. Weed Res. 2003, 43, 77-89. [CrossRef]

5. Lewis, T.D.; Rowan, J.S.; Hawes, C.; McKenzie, B.M. Assessing the significance of soil erosion for arable weed seedbank diversity in agro-ecosystems. Prog. Phys. Geogr. 2013, 37, 622-641. [CrossRef]

6. Valentine, T.A.; Hallett, P.D.; Binnie, K.; Young, M.W.; Squire, G.R.; Hawes, C.; Bengough, A.G. Soil strength and macropore volume limit root elongation rates in many UK agricultural soils. Ann. Bot. 2012, 110, 259-270. [CrossRef] [PubMed]

7. Kleijn, D.; Sutherland, W.J. How effective are European agri-environment schemes in conserving and promoting biodiversity? J. App. Ecol. 2003, 40, 947-969. [CrossRef]

8. Overview of CAP Reform 2014-2020. EC Agricultural Policy Perspectives Brief No. 5. 2013. Available online: https:/ / eige.europa.eu/resources/05_en.pdf (accessed on 13 November 2017).

9. Pretty, J.; Bharucha, Z.P. Sustainable intensification in agricultural systems. Ann. Bot. 2014, 114, 1571-1596. [CrossRef] [PubMed]

10. McKenzie, B.M.; Bengough, A.G.; Hallett, P.D.; Thomas, W.T.B.; Forster, B.; McNicol, J.W. Deep rooting and drought screening of cereal crops: A novel field-based method and its application. Field Crops Res. 2009, 112, 165-171. [CrossRef]

11. White, P.J.; George, T.S.; Gregory, P.J.; Bengough, A.G.; Hallett, P.D.; McKenzie, B.M. Matching roots to their environment. Ann. Bot. 2013, 112, 207-222. [CrossRef] [PubMed]

12. Brooker, R.W.; Bennett, A.E.; Cong, W.-F.; Daniell, T.J.; George, T.S.; Hallett, P.D.; Hawes, C.; Iannetta, P.P.M.; Jones, H.G.; Karley, A.J.; et al. Improving intercropping: A synthesis of research in agronomy, plant physiology and ecology. New Phytol. 2015, 206, 107-117. [CrossRef] [PubMed]

13. Tilman, D.; Cassman, K.G.; Matson, P.A.; Naylor, R.; Polasky, S. Agricultural sustainability and intensive production practices. Nature 2002, 418, 671-677. [CrossRef] [PubMed]

14. Goulding, K.; Jarvis, S.; Whitmore, A. Optimising nutrient management for farm systems. Philos. Trans. R. Soc. B. 2008, 363, 667-680. [CrossRef] [PubMed]

15. Hawes, C.; Begg, G.S.; Iannetta, P.; Karley, A.; Squire, G.R. A whole-systems approach for assessing measures to improve arable ecosystem sustainability. Ecosyst. Health Sustain. 2016, 2, e01252. [CrossRef] 
16. Hawes, C. Assessing the impact of management interventions in agroecological and conventional cropping systems using indicators of sustainability. In Agroecological Practices for Sustainable Agriculture: Principles, Applications, and Making the Transition; Wezel, A., Ed.; Imperial College Press: London, UK, 2017; pp. $229-262$.

17. Dungait, J.A.J.; Ghee, C.; Rowan, J.S.; McKenzie, B.L.; Hawes, C.; Dixon, E.R.; Paterson, E.; Hopkins, D.W. Microbial responses to the erosional redistribution of soil organic carbon in arable fields. Soil Biol. Biochem. 2013, 60, 195-201. [CrossRef]

18. Hillier, J.; Hawes, C.; Squire, G.R.; Hilton, A.; Wale, S.; Smith, P. The Carbon Footprints of Food Crop Production. Int. J. Agric. Sustain. 2009, 7, 107-118. [CrossRef]

19. Sparks, D.L. Methods of Soil Analysis Part 3: Chemical Methods. In Cation Exchange Capacity, and Exchange Coefficients; Soil Science Society of America/American Society of Agronomy: Madison, WI, USA, 1996.

20. Brenchley, W.A.; Warington, K. The weed seed population of arable soil. II. Influence of crop, soil and methods of cultivation upon the relative abundance of viable seeds. J. Ecol. 1933, 21, 103-127. [CrossRef]

21. Roberts, H.A. Studies on the weeds of vegetable crops. I. Initial effects of cropping on the weed seeds in the soil. J. Ecol. 1958, 46, 759-768.

22. Roberts, H.A.; Chancellor, R.J. Seed banks of some arable soils in the English Midlands. Weed Res. 1986, 26, 251-257. [CrossRef]

23. Heard, M.S.; Hawes, C.; Champion, G.T.; Clark, S.J.; Firbank, L.G.; Haughton, A.J.; Parish, A.M.; Perry, J.N.; Rothery, P.; Scott, R.J.; et al. Non-crop plants in fields with contrasting conventional and genetically modified herbicide-tolerant crops. 1. Main effects of treatments. Philos. Trans. R. Soc. Lond. B 2003, 358, 1819-1832.

24. Debeljak, M.; Squire, G.R.; Demšar, D.; Young, M.; Džeroski, S. Relations between the oilseed rape volunteer seedbank, and soil factors, weed functional groups and geographical location in the UK. Ecol. Mod. 2008, 212, 138-146. [CrossRef]

25. Hawes, C.; Squire, G.R.; Hallett, P.D.; Watson, C.A.; Young, M. Arable plant communities as indicators of farming practice. Agric. Ecosys. Environ. 2010, 138, 17-26. [CrossRef]

26. Hawes, C.; Haughton, A.J.; Osborne, J.L.; Roy, D.B.; Clark, S.J.; Perry, J.N.; Rothery, P.; Bohan, D.A.; Brooks, D.R.; Champion, G.T.; et al. Responses of plant and invertebrate trophic groups to contrasting herbicide regimes in the Farm Scale Evaluations of genetically-modified herbicide-tolerant crops. Philos. Trans. R. Soc. Lond. B 2003, 358, 1899-1913.

27. Altieri, M.A. The ecological role of biodiversity in agroecosystems. Agric. Ecosyst. Environ. 1999, 74, $19-31$. [CrossRef]

28. Mengel, K.; Hutsch, B.; Kane, Y. Nitrogen fertiliser application rates on cereal crops according to available mineral and organic soil nitrogen. Eur. J. Agron. 2006, 24, 343-348. [CrossRef]

29. Kirchmann, H.; Kätterer, T.; Bergström, L. Nutrient Supply in Organic Agriculture-Plant Availability, Sources and Recycling. In Organic Crop Production-Ambitions and Limitations; Kirchmann, H., Bergström, L., Eds.; Springer: Dordrecht, The Netherlands, 2009; pp. 89-116.

30. Burchill, W.; James, E.K.; Li, D.; Lanigan, G.J.; Williams, M.; Iannetta, P.P.M.; Humphreys, J. Comparisons of biological nitrogen fixation in association with white clover (Trifolium repens L.) under four fertiliser nitrogen inputs as measured using two ${ }^{15} \mathrm{~N}$ techniques. Plant Soil 2014, 385, 287-302. [CrossRef]

31. Jones, L.; Clements, R.O. Development of a low input system for growing wheat (Triticum vulgare) in a permanent understorey of white clover (Trifolium repens). Ann. Appl. Biol. 2008, 123, 109-119. [CrossRef]

32. Isbell, F.; Adler, P.R.; Eisenhauer, N.; Fornara, D.; Kimmel, K.; Kremen, C.; Letourneau, D.K.; Liebman, M.; Polley, H.W.; Quijas, S.; et al. Benefits of increasing plant diversity in sustainable agroecosystems. J. Ecol. 2017, 105, 871-879. [CrossRef]

33. Andreasen, C.; Stryhn, H. Increasing weed flora in Danish arable fields and its importance for biodiversity. Weed Res. 2008, 48, 1-9. [CrossRef]

34. Storkey, J.; Westbury, D.B. Managing arable weeds for biodiversity. Pest Manag. Sci. 2007, 63, 517-523. [CrossRef] [PubMed]

35. Bohan, D.A.; Powers, S.J.; Champion, G.; Haughton, A.J.; Hawes, C.; Squire, G.R.; Cussans, J.; Mertens, S.K. Modelling rotations: Can crop sequences explain arable weed seedbank abundance? Weed Res. 2011, 51, 422-432. [CrossRef]

36. Zimdahl, R.L. Weed-Crop Competition: A Review, 2nd ed.; Blackwell Publishing: Oxford, UK, $2004 ;$ p. 219. ISBN 0-8138-0279-2. 
37. Morris, N.L.; Miller, P.C.H.; Orson, J.H.; Froud-Williams, R.J. The adoption of non-inversion tillage systems in the United Kingdom and the agronomic impact on soil, crops and the environment-A review. Soil Till. Res. 2010, 108, 1-15. [CrossRef]

38. Holland, J.M. The environmental consequences of adopting conservation tillage in Europe: Reviewing the evidence. Agric. Ecosys. Environ. 2004, 103, 1-25. [CrossRef]

39. Bond, W.; Grundy, A.C. Non-chemical weed management in organic farming systems. Weed Res. 2001, 41, 383-405. [CrossRef]

40. Abdul-Salam, Y.; Hawes, C.; Roberts, D.; Young, M. The economics of conventional and integrated crop production systems in the context of farmer participation in carbon trading markets-A case study of Scotland. Int. J. Sustain. 2018, in press.

2018 by the authors. Licensee MDPI, Basel, Switzerland. This article is an open access article distributed under the terms and conditions of the Creative Commons Attribution (CC BY) license (http://creativecommons.org/licenses/by/4.0/). 